\title{
Mother as an Active Classroom Learning Facilitator in Early Educational Program
}

\author{
Farah Farida Tantiani \\ Faculty of Psychology, Malang State University \\ Corresponding e-mail: tantiani@yahoo.com
}

\begin{abstract}
At present, early childhood education is no longer just reserved for children aged 4-5 years who want to prepare for formal schooling at primary school. Early childhood education also provides facilities for children with younger age, like a play groups for toddlers and baby classes. With younger age children entering the school, the role and responsibilities of teachers in early childhood education (ECE) also known as Pendidikan Anak Usia Dini (PAUD) in Indonesian language, was greater for educating these children. On the other hand, parents need to be aware that the main responsibility for the education of children was in their hands than in the hands of school teachers. But this is not the case in some cities. In several PAUD in Malang, East Java, it can be seen the sights where the mother was present in the classroom. This situation usually become the issues to be solved by trying to separate the mother from their children during the learning process in the classroom. This article is trying to see this problems from different view: why not benefiting the presence of the mother in the classroom as one of the learning facilitator also. This article will be discussing the efforts of the active involvement of mother in early childhood education classroom in terms of being the active learning facilitator for their own children. This article is based on several literatures on the role of parents and early childhood education, which may be more effective to be applied in Indonesia, especially in the area of Malang, East Java.
\end{abstract}

Keywords: early educational program, mother and child relationship, classroom learning facilitator

\section{INTRODUCTION}

The changes in economic growth increase the number of dual-earner families. When both parents work outside the house, the child-rearing process is affected, because children of dual-earner families are indirectly influenced by their parents' occupational status. The quality and quantity of parent-child interaction, role modeling and degree of involvement with other caregivers and peers are affected by mothers and fathers work responsibility (Martin \& Colbert, 1997). In Indonesia, where both parents are working outside the house, the parents usually got help from their relatives, such as the grandparents and/or aunties, in the childrearing process. If the parental work demand cause the families to move away from relatives, they usually hire a nanny or send their children to daycare center or even to the school, even though their children age are still in toddler years. The later alternatives seems to gain more popularity among parents because there has been extensive discussion about the benefits of early childhood education for the long term effects in their children development that carries into adulthood.

The needs of working parents seems not the only reason early childhood education has been gaining public attention. According to Essa (1996) the success of publicly funded programs such as Head Start has shown that high-quality early educational intervention can combat poverty and dysfunction. There has been extensive discussion and research about the benefits of early education for special populations of children and families, like children from poverty backgrounds, children with handicaps and children at risk. Researchers have concluded that good early childhood programs are not only improve the lives of the children and families involved but also result in substantial economic benefits for society. 
Indonesia also acknowledge the importance of early childhood education because of the benefits that comes with it in western countries. Nowadays, we can find almost anywhere in Indonesia the institution that provide the early childhood education services. In Indonesia the services known by the name PAUD (Acronym for Pendidikan Anak Usia Dini) under supervision of Ministry of Education. The family who can benefited from this services are not only a high-income family or an urban family, whom the main users of early childhood education programs, but also from rural areas. This also means that more people participated in supporting the early childhood education because the needs to improve the development of every aspect of development in their children. According to Essa (1996), major purpose of many ECE programs is to care for children while their parents work, so the primary goal of child care programs is to provide safe and nurturing care in developmentally appropriate setting for children. The second aim is for enrichment, to enhance socialization, cognitive skills or overall development of young children. The third major purpose is compensation to make up for some lack in children's backgrounds.

PAUD programs also can be found in Malang, East Java, but usually the family who join the programs are not only coming from dual-earner family but also from single-earner family. It means that there's also an involvement from non-working mother. Some of the reason why non-working mother entering their children to PAUD is because by sending their children to PAUD for amount of time in a day, the mother can finished other work, such as cleaning the house, taking care of the younger child who is not entering PAUD yet, and so that the mother can have 'me time' to take care of themselves. Nonetheless, in one PAUD in Malang, we can find the mother also present in the classroom and helping their children doing what the teacher instructed their children to do or simply just present and sit in the classroom corner without doing anything waiting for their children activities over. The reason for this is usually because the children does not want to be separated from their mother, so the teacher gives the privilege for the mother to be present in the classroom also. But because of the size of PAUD classroom is small and many people were present in classroom, the classroom become quite full and hectic. The teacher have to spend extra effort to manage the classroom in order to be able to support optimal development to their student. In order to better managing the classroom activities, usually the teacher will give the mother limited time to be present in the classroom. The mother was allowed to be present in the classroom just for 3 days counting from the first day their children came to school.

The separation process between mother and children in the classroom are not always come smoothly. It often caused stress in everyone involved: the children, the mother and also the teacher. Children may become scared and not enjoying the school activities anymore, even it may cause them not going to PAUD anymore. The teacher may have to be very busy dividing attention between the children in the classroom and the child who have a hard time separating from their mother. The mother also may have to listen to their children crying and may cause them to withdrawn their children from PAUD activities. Since the separation process often stressful for everyone involved, some PAUD allowing the children mother to be present in the classroom as their helper so that the teacher can focus on teaching other children that already independent on their own.

As the helper of their own child, the mother actually only moving the activities of teaching their children from home to PAUD. Since the mother directly instructing and guiding their children in the classroom, they still are the main source of learning for their children. The benefit from having the mother in the classroom is that the mother also learn many different skills from the teacher to teach their children at home. After all, the main responsibility to guide the children to their optimal development lies in the hand of their parents, especially in early childhood age period. According to Notosoedirdjo and Latipun (2002), mother role is very important, especially from the interaction with their mother, the children learn about socialization. Mother also has the important role in helping their children develop the emotional aspect. If the mother does not have enough time to interact with their children, the children will have difficult time to learn the skill to socialize and might be interfere with healthy upbringing and might harm their mental health. This article is trying to discuss how to benefit the mother present in the PAUD classroom practice in some Indonesian PAUD.

\section{EARLY CHILDHOOD EDUCATION PROGRAM IN INDONESIA}

Early childhood education program in Indonesia is called PAUD. PAUD is some kind of schooling and/or child-care activities intended for younger 
children, age six until eight, in order to give the early experiences in many areas, such as learning process, socialization process and introduce the children about the rules outside the house so they are ready to enter next education level (Based on Undang-undang RI No.20 year 2003 about National Educational System). According to Dirjen Pendidikan Nonformal \& Informal (PNFI), PAUD have a mission to improve the educational service equity, the quality and efficiency of early childhood educational programs, and increase awareness about early childhood educational services (Sudjiono, 2013).

PAUD can be held in formal, nonformal or informal ways. In formal ways, the government provides Kindergarten or RA (Raudathul Atfhal). In nonformal ways, citizen can held their own PAUD according to their needs, especially those who doesn't have the privilege to be served in formal schooling, such as Kindergarten or RA. While informal ways can be held in family or neighborhoods, usually intended to teach about religion, cultural values, moral values, ethics, etc. According to Sujiono (2013), PAUD in Indonesia can be found in several form, such as Kindergarten or RA, the formal early childhood educational programs which intended for older children, age 4 to 6 years old. Schooling time in Kindergarten usually start at 7 or 8 o'clock and last until 10 or 11 o'clock and most of their activities are intended to prepare them the readiness skills for elementary programs, such as academic skills and social skills. For younger children, age 2 until 4 years old, there are play groups programs, called kelompok bermain (KB). The activities held in $\mathrm{KB}$ usually in the form of playing with the shorter school timing (only for 2-3 hours/days). In KB, the children does not have to come every day from Monday to Friday/Saturday, but they only came 3 days in a week. Another form of PAUD in Indonesia is daycare, or usually called Tempat Penitipan Anak (TPA). TPA is very useful for parents who have to go to work but does not have any relatives or caretaker that can stay with their children at home. TPA provided the place and programs (some) to take care of the children for some time when their parents are working. TPA also targeting children age 0 to 6 years old.

In practice, PAUD activities can be based on several theory and method about early educational programs curriculum, such as Montessori which is widely used in PAUD. Montessori saw education as assisting the psychological development of children rather than as teaching per se (Roopnarine \& Johnson, 2005). Montessori believes that the child is naturally eager for knowledge and capable of initiating learning in supportive, thoughtfully prepared learning environment. In order to be considered as authentically Montessori programs, there are few components necessary included, such as multiage groupings that foster peer learning, uninterrupted blocks of work time \& guided choice of work activity (American Montessori Society, 2016 from http://amshq.org/MontessoriEducation/Introduction-to-Montessori).

Besides Montessori, other PAUD activities also based on Ki Hajar Dewantara, one of Indonesian pioneer in education development. Ki Hajar Dewantara believes that the important point of teaching young children is in character development and moral guidance (Budi Pekerti dan Sistem Among). According to Ki Hajar Dewantara, it is important implanting the good value not just teaching them in order to build a strong character person (Sujiono, 2013). PAUD need to teach the traditional value, ethics and decent behavior that can be achieve trough models such behavior, through the stories or fable and playing. To make it happen, the teacher need to be very creative and innovative. For $\mathrm{Ki} \mathrm{Hajar,} \mathrm{the} \mathrm{best} \mathrm{way} \mathrm{to} \mathrm{teach} \mathrm{children} \mathrm{age} \mathrm{1-7}$ years old is by giving good example and conditioning them to make a good habit. Ki Hajar also believes that the teacher needs to give the children the 'spotlight' and just following them from behind, giving the children an active role and just be the facilitator to help them find their true self.

\section{SCHOOL, PARENTS AND COMMUNITY}

According to Bronfenbrenner's bioecological theory of human development, the child developments involve the environment surrounding them, known as microsystems, mesosystems, ecosystems and macro systems (Berns, 2013). This theory propose that in order to explain individual differences, one must look various ecological settings in which the child participates, such as family, school environment and how the children interaction between them. This means that interaction between PAUD teachers, the parents, and the children is very important to be considered so the children can grow and developed optimally.

With increasing numbers of children join PAUD, parents and teachers becoming partners in many aspect of child rearing and socialization (Essa, 1996). Studies have shown that the children benefits when parents and teacher/early childhood staff share a common commitment to the best interest in children, communicate openly and have mutual respect. Gestwicki (2007) also believes that families must be included in developmentally appropriate 
programs for young children as a resources for understanding individuality and as partners in setting goals, assessing children's progress, and planning for the continuity of educational experiences.

Morrison (2012) said that accountabilities and reform movement in ECE has clearly convince us that the family no longer needed to be dissociated from school activities. He stated that by involving the families in educational process, it helps parents and other family members to use their ability for their own interest as well as their children and the ECE. In order to make the collaboration success, all parties must be able to work together toward the same goal, to optimize the children development in all developmental aspects.

The school first was built with intention so that people able to learn in spare time, based on the meaning of the word skhole, scola, scolae or schola which is leisure devoted to learning (Topatimasang, 1998). The parents sent their children to school because they do not have many times to teach their own children many things, so they let their children learnt from other person that the parents trust or they know other family already learnt. This means that the mother who is not working outside the house can educate their children in person, not by sending them to school. Usually the age of the children that they sent to school is not as young as nowadays. Children, whose age is under 6 or 7 years old still under the full rearing of their mothers. In Indonesia, especially in Java, the same tradition apply. The mother has full responsibility to raise their children until they ready to enter elementary school. The mother responsibility including to teach their children manners, ethics, moral and good values in Javanese wisdom. The role of the father only later introduce to the children, after they enter the elementary school (Geertz, 1983).

In the present days, children entering school from early age because the parents have to work outside the house and the best alternative place for helping them to guiding their children is in the school. The age span of early childhood educational programs including children as young as after birth until age eight, which includes infants, toddlers, preschoolers, kindergarteners and children in primary grades. It is because working parents need care for their children of varying ages. Actually, it is noted that one of the most dramatic increases in recent years has been in infant and toddler programs. The benefits of children who join PAUD makes it a favorite choice among parents from dual earners family. This includes the independency for their children to achieve, being able to taking care of themselves and also help them to learn some basic academic skills, such as listening, writing, reading, counting and also in making friends.

In the case of non-working mother but still have to be present in the classroom, usually the mother thinks that the best activities for their young children is available in PAUD. As a consequences, the mother accompany their children to PAUD until the PAUD activities finished for that day. The activities that the mother who accompany their children in PAUD engaging is divided by two kinds of activities. One is that they accompany their children in the classroom, sit together with their children and helping them to do their task; while the other is that the mother does not stay in their children classroom but waiting outside with other mothers and engaging in small talks. This activities was considered as wasting time, so some school try to give the mother activities that considered more meaningful, such as parenting classes or recite the Qur'an (for Islamic parenting group), besides involving them to the parent teacher association who have regular agenda.

The school acknowledge the important of parent involvement in their school activities, but they also kept the minimum involvement of the parents. On the other end, the main responsibility, as already discussed above, for educating their young children lies in the hand of the parents. So when they have the situation that the mother is not working and want to accompany their children in the classroom, it is make sense that the teacher can involving the mother to also be the facilitator to help their children to learn. If in the classroom only one children who needed the mother accompany, maybe the teacher can ask the mother to also help her with the task instruction and observe how the other children are doing in the task at hand.

By involving the mother as an active learning facilitator, the children will be in contact with their friends. When the children know their friends, they will be more familiar with their surroundings. It can also be expected that they are more comfortable to be independent without having to force the separation with the mother. The mother also benefiting from learning new skills that can be transferred to their children at home or other children in the neighborhood who does not have the privilege to go to school such as PAUD. The teacher also benefits from the extra facilitator in the classroom: she got extra help to run the classroom activities.

The spirit of education for all that include the special needs children to join regular classroom by 
the inclusion educational programs, also can benefiting from the involvement of parents in the classroom. The special needs children usually needs some help to be able to learn some materials like their other friends. The help maybe include shadow teacher. By becoming their children shadow teacher, the parents have the opportunity to be their child's primary interventionist. Because the parents, usually the mother, are present in the classroom, they have the consistencies about the way materials delivered to their children and by knowing the task and materials being delivered to their children, that they can teach them later at home.

\section{CONCLUSIONS}

PAUD personnel's should ask the non-working mother who accompany their children in the classroom to be their partner in teaching the children. The join forces among PAUD teachers and the mothers proved that there are so many benefits in the mother involvement in the classroom activities, i.e. the mother can learn the skills needed to guide their children development, the teacher also have a helpful partner in managing the classroom, and the children also have the benefits to become more independent. This can also be applied in many situations, involving wide range of children, including the special needs children. This article suggest that instead of excluding the mother in the classroom learning process, it is better to involving them as an active learning facilitator in the classroom.

\section{REFERENCES}

Essa, Eva (1996) Introduction to early Childhood Education New York: Delmar Publishers

Berns, Robert (2013) Child, Family, School, Community: Socializing and Support USA: Wadsworth, Cengage Learning

Geertz, Hildred (1983) Keluarga Jawa, Jakarta: Grafiti Pers

Gestwicki, Carol (2007) Developmentally Appropriate Practise: Curriculum and Development in Early Education, $3^{\text {rd }}$ ed, New York: Thomson Delmar Learning

Johnson, J.E (2005) Approaches to Early Childhood Education, $4^{\text {th }}$ ed, New Jersey: Pearson Education, Inc

Martin, Carole A \& Colbert, Karen, K (1997) Parenting: A Lifespan Perspective, New York: The McGraw-Hill Companies, Inc.
Morrison, George S (2012) Dasar-Dasar Pendidikan Anak Usia Dini (PAUD), 5th edIndonesian Edition, Jakarta: PT Indeks

Notosoedirdjo, M \& Latipun (2002) Kesehatan Mental: Konsep dan Penerapan. Malang: Universitas Muhammadiyah Malang

Roopnarine, Jaipaul L \& Johnson, James E (2005) Approaches to Early Childhood Education, $4^{\text {th }}$ $e d$, New Jersey: Pearson Education, Inc.

Sujiono, Y.N (2013) Konsep Dasar Pendidikan Anak Usia Dini, Jakarta: Indeks

Topatimasang, Roem (1998) Sekolah itu Candu, Yogyakarta: Pustaka Pelajar

http://amshq.org/MontessoriEducation/Introduction-to-Montessori (2016) 